\title{
Krajowa sieć onkologiczna
}

\author{
Krzysztof Warzocha
}

Przedrukowano za zgodą z czasopisma Hematologia 2014, tom 5, nr 1, 1-21

W artykule przedstawiono projekt funkcjonowania krajowej sieci onkologicznej w Polsce w oparciu o standaryzację postępowania diagnostyczno-leczniczego w podmiotach leczniczych certyfikowanych poziomem referencyjności i zakresem kompetencji realizujących świadczenia onkologiczne ze środków publicznych.

\section{National oncology network}

This article describes an operational model for the national oncology network in Poland based on standardised diagnostic and treatment working practices performed accordingly to defined levels of referentiality and competence, at certified medical centres that are covered by the national health fund.

NOWOTWORY Journal of Oncology 2014; 64, 2: 143-162

Słowa kluczowe: wielospecjalistyczne centrum onkologii, centrum onkologii, centrum kompetencji, centrum doskonałości, ambulatoryjna opieka specjalistyczna, referencyjność, zakres kompetencji, audyt, nowotwory, diagnostyka, leczenie

Key words: comprehensive cancer centre, cancer centre, centre of competence, centre of excellence, specialised outpatient clinic, referral levels, certificate of competence, audit, neoplasms, diagnosis, treatment

\section{Wprowadzenie}

W artykule na temat projektu utworzenia Narodowego Instytutu Onkologii i Hematologii opublikowanym w ubiegłorocznym numerze „Hematologii" [1] oraz przedrukowanym w czasopismach „Onkologia w Praktyce Klinicznej” [2] i,Nowotwory” [3] wskazano, że podstawami najskuteczniejszych systemów opieki onkologicznej na świecie są dostęp i racjonalne wykorzystywanie wszystkich zasobów krajowych według ściśle określonych zasad organizacyjnych i zakresów kompetencji podmiotów leczniczych. Podkreślano, że zasadnicze znaczenie ma optymalizacja diagnostycznej i terapeutycznej ścieżki chorego poprzez jej standaryzację, wcześniejsze planowanie, kompleksową realizację, koordynację i monitorowanie w trakcie wielospecjalistycznego leczenia sekwencyjnego oraz po jego zakończeniu.

„Obowiązujący" obecnie w Polsce stopień referencyjności świadczeniodawców jest uznaniowy, a nie certyfikowany, zaś jakość udzielanych w nich świadczeń — deklarowana, a nie audytowana. Nie do zaakceptowania są nierównomierna dostępność do świadczeń diagnostyczno-terapeutycznych w różnych regionach kraju oraz niewystarczające skuteczność i bezpieczeństwo leczonych chorych na nowotwory. Dużym problemem pozostaje rozproszenie realizacji świadczeń onkologicznych i kadry medycznej w oderwaniu od rzeczywistych potrzeb epidemiologicznych i już istniejących świadczeniodawców w danym regionie. Komercjalizacja niesie za sobą preferencję do wykonywania procedur przynoszących korzyści ekonomiczne, a w ich kontraktowaniu z Narodowym Funduszem Zdrowia (NFZ) nie uwzględnia się kompleksowości świadczeń. W efekcie wolny rynek świadczeń medycznych, zamiast zwiększać jakość opieki onkologicznej, powoduje jej deprecjację oraz prowadzi do pogorszenia sytuacji finansowej pełnoprofilowych, wielospecjalistycznych centrów onkologii, które poza procedurami dobrze wycenionymi (radioterapia, chemioterapia w trybie 1-dniowym) realizują liczne świadczenia 
niedoszacowane, w tym: specjalistyczną diagnostykę patologiczno-cytogenetyczno-molekularną, porady specjalistyczne, świadczenia szpitalne związane z wykonywaniem dużych zabiegów operacyjnych i złożonych protokołów chemioterapii, leczeniem powikłań choroby nowotworowej lub jatrogennych oraz procedur z zakresu intensywnej opieki medycznej, chorób wewnętrznych, hematologii, mikrobiologii, rehabilitacji, psychoonkologii i medycyny paliatywnej.

Tymczasem doświadczenia krajów uprzemysłowionych jednoznacznie wskazują na to, że system opieki onkologicznej nie może być zbudowany na zasadach konkurencji wolnorynkowej, ale — w zamian — w jego ramach powinny funkcjonować precyzyjnie zdefiniowane narzędzia i mechanizmy regulacji. Omówiono je szczegółowo we wspomnianym artykule dotyczącym roli i miejsca w krajowej sieci onkologicznej wielospecjalistycznych centrów onkologii (WCO), Centrum Onkologii — Instytutu im. Marii Skłodowskiej-Curie (CO-I) oraz Instytutu Hematologii i Transfuzjologii (IHT) - mogących stanowić bazę dla Narodowego Instytutu Onkologii i Hematologii ( $\mathrm{NIOH}$ ) — oraz Krajowej Rady ds. Onkologii i Hematologii (KROH) [1-3]. Nad tymi problemami dyskutowano również w innych publikacjach [4-6]. Niniejszy artykuł stanowi ich uzupełnienie, ze szczególnym zwróceniem uwagi na potrzebę i sposoby wprowadzania standaryzacji postępowania diagnostyczno-leczniczego oraz poziomów referencyjności i zakresów kompetencji podmiotów leczniczych udzielających świadczeń onkologicznych ze środków publicznych.

\section{Rola skojarzonej, wielospecjalistycznej opieki kompleksowej}

Istotą udzielania onkologicznych świadczeń diagnostyczno-leczniczych jest uzyskanie maksymalnej skuteczności terapii przeciwnowotworowej przy zachowaniu maksymalnego bezpieczeństwa realizacji procedur potencjalnie zagrażających życiu pacjenta (minimum powikłań). Dla powodzenia terapii istotne są sekwencja, rodzaj i zakres interwencji, w tym: dotyczących rozpoznania nowotworu, oceny jego lokalizacji i stopnia zaawansowania, leczenia systemowego, chirurgicznego, radioterapeutycznego, wspomagającego, a także świadczeń profilaktycznych oraz świadczeń z zakresu hematologii, interny, kardiologii, mikrobiologii, medycyny paliatywnej i psychoonkologii, a nawet transplantologii i medycyny rekonstrukcyjnej. Przedstawiciele poszczególnych specjalności mogą mieć odmienne koncepcje postępowania, konieczne jest zatem wypracowanie wspólnego stanowiska w celu zapewnienia wyboru najlepszej metody oraz uniknięcia wykonywania niepotrzebnych i wzajemnie wykluczających się procedur, w tym także usunięcie obaw i wątpliwości chorego.

W tym celu towarzystwa naukowe zalecają opracowywanie indywidualnego planu leczenia dla poszczególnych chorych przez zespoły wielodyscyplinarne (MDT, multidisci- plinary team). Zwykle zaleca się, aby w ich skład wchodzili przedstawiciele co najmniej trzech głównych specjalności lekarskich, w tym onkologii klinicznej oraz chirurgii i radioterapii onkologicznej, czasem przy współudziale specjalistów z innych dziedzin medycyny. Zespoły te powinny uwzględniać zdanie chorego dotyczące proponowanej metody leczenia oraz - w przypadkach, w których jest to możliwe — przedstawiać mu alternatywne metody. W praktyce należy dążyć do tego, aby dla wszystkich chorych z nowo rozpoznanym nowotworem zostały zdefiniowane podstawowe etapy postępowania onkologicznego, w tym kompleksowy proces diagnostyczny pozwalający na ustalenie histopatologicznego typu nowotworu, jego lokalizacji i zaawansowania oraz kompleksowy, indywidualny plan leczenia uzgadniany z pacjentem, a także zostały określone zasady rehabilitacji i obserwacji po zakończeniu leczenia, również w ramach ambulatoryjnej opieki specjalistycznej (AOS) i podstawowej opieki zdrowotnej (POZ).

Obecnie wyżej wymienione cele mogą być skutecznie realizowane w WCO, gdzie dostępna jest niezbędna baza diagnostyczna i lecznicza w wymaganych do tego zakresach. Alternatywą może być postępowanie rozdrobnione do innych ośrodków posiadających określony poziom referencyjności i zakres kompetencji, jednak pod warunkiem działania skoordynowanego na podstawie wcześniej przygotowanej opinii specjalistów wchodzących w skład MDT i koordynatora procesu diagnostyczo-leczniczego. Podmiot koordynujący nie musi samodzielnie przeprowadzać całego wieloetapowego procesu, ale musi zapewnić jego kompleksowość, za którą powinien otrzymać należną refundację, którą w uzasadnionych przypadkach może dywersyfikować na ewentualnych podwykonawców w ramach umów cywilnoprawnych.

To, że dziś nakłady na onkologię się zwiększają (4-krotnie w ciągu ostatnich 10 lat), a wskaźniki wyleczalności w tym czasie się nie zmieniły i wciąż, od początku lat 90. ubiegłego wieku, pozostają na poziomie około $40 \%$, wynika między innymi z faktu, że w ośrodkach o niższym poziomie referencyjności realizowane są tylko wybrane procedury terapeutyczne, a dostęp do kompleksowej diagnostyki i leczenia w tych ośrodkach jest ograniczony lub w ogóle niemożliwy. Wielokrotne „przekierowywanie" chorych na dalsze leczenie do ośrodków, w których jest dostępny inny zakres leczenia niż w poprzednim ośrodku — często bez wcześniejszego planu takiej sekwencji zdarzeń — skutkuje niepotrzebnym wydłużaniem czasu do zakończenia leczenia o charakterze radykalnym (ukierunkowanym na wyleczenie), co w sytuacji chorych na nowotwory przekłada się na wyższe ryzyko niepowodzenia, natomiast dla narodowego płatnika oznacza wyższe koszty refundacji, powiększone o leczenie ratunkowe i paliatywne.

Wielospecjalistyczna opinia MDT powinna stanowić rozliczany produkt kontraktowy z NFZ, z wymogiem prze- 
prowadzenia takiej konsultacji w celu pełnego rozliczenia poszczególnych elementów procesu leczniczego włącznie. Należy również rozważyć możliwość ryczałtowej refundacji kosztów wstępnej diagnostyki i oceny stopnia zaawansowania nowotworu nie na podstawie przeprowadzenia tylko wybranych badań dodatkowych, ale w oparciu o zintegrowane raporty patologiczne i diagnostyki obrazowej, odpowiednio zgodne z wymogami klasyfikacji nowotworów Światowej Organizacji Zdrowia (WHO, World Health Organization) i klinicznych stopni zaawansowania według TNM (tumor, nodes, metastases) lub specyficznych dla danej grupy nowotworów.

Ze względu na coraz większą liczbę chorych na nowotwory należy mieć na uwadze, że nie wszyscy pacjenci będą mogli być leczeni w ośrodkach wielospecjalistycznych („pod jednym dachem"), dlatego stworzenie bazy jednostek satelitarnych w ścisłej współpracy z ośrodkiem koordynującym może zapewnić zarówno nadzór merytoryczny, jak i szerszy dostęp do leczenia skojarzonego. Tylko współpraca, a nie współzawodnictwo (konkurencja) w tym zakresie pozwoli na zapewnienie najwyższej jakości świadczeń medycznych. Dlatego idea zwiększenia dostępności do leczenia kompleksowego w ośrodku wielospecjalistycznym lub — w sposób zaplanowany i skoordynowany - w kilku ośrodkach jest niezmiernie ważna. W przypadku nowotworów rzadko występujących należy dążyć do tego, aby leczenie było prowadzone wyłącznie w ośrodkach doświadczonych w ich diagnozowaniu i leczeniu. Ponadto po wyleczeniu lub w przypadku opieki terminalnej pacjenci powinni być stopniowo przekazywani z AOS do POZ, za dodatkową refundacją i/lub po podwyższeniu średniej stawki kapitacyjnej.

Przedmiotem wyżej wymienionej koordynacji byłyby planowanie i organizacja określonej sekwencji procedur medycznych prowadzących do założonego celu diagnostycznego lub terapeutycznego w ramach jednej lub wielu placówek ochrony zdrowia. Taka koordynacja służy osiągnięciu najwyższej skuteczności podejmowanych działań, przy zachowaniu najwyższej efektywności wykorzystania zasobów w regionie oraz ograniczeniu niepewności i niepokoju ze strony pacjenta, wynikających z braku znajomości reguł działania systemu oraz podziału kompetencji i ról w tym systemie. Wszystkie elementy koordynacji organizacyjnej, takie jak udzielenie informacji telefonicznej, prowadzenie strony internetowej, list oczekujących itp., powinny być maksymalnie dostępne i nakierowane na odciążenie personelu medycznego od czynności pozamedycznych.

Docelowo zarówno indywidualny plan leczenia, jak i program opieki po zakończeniu terapii powinny mieć ujednoliconą w całym kraju elektroniczną formę dostępną dla wszystkich świadczeniodawców, chorego i pracowników ochrony zdrowia uczestniczących w kolejnych etapach procesu. Alternatywą mogłoby być zastosowanie ujednoliconych papierowych formularzy służących do planowania i realizacji procesu leczenia („,indywidualna książeczka chorego").
Wspólnym mianownikiem powyższych rozwiązań jest koncepcja koordynacji opieki, często z jednoczesną funkcjonalną lub organizacyjną integracją opieki onkologicznej. Skoncentrowanie działań na chorym w miejsce koncentracji na procedurze, a także udział pacjenta w całym procesie diagnostycznym, leczniczym i rehabilitacyjnym powinny się stać zasadniczym celem zmian w polskim systemie opieki onkologicznej. Cel ten nie jest niczym nowym i funkcjonował w przeszłości jako organizacyjna konieczność zapewnienia choremu ciągłości opieki specjalistycznej [7].

\section{Standaryzacja świadczeń diagnostyczno-leczniczych}

Obecnie podstawami postępowania medycznego u chorych na nowotwory w Polsce są wyłącznie zalecenia lub wytyczne towarzystw naukowych. Obowiązujące przepisy niczego nie zakazują ani nie nakazują, dlatego praktyka kliniczna dopuszcza dowolność postępowania diagnostycznego i leczniczego, w tym różnice takiego postępowania w przypadku identycznych problemów zdrowotnych. Należą do nich także działania niezgodne ze sztuką medyczną poprzez nieprawidłowe kwalifikowanie chorych do określonej metody leczniczej lub w niewłaściwej sekwencji leczenia skojarzonego, stosowanie szkodliwych — zawyżonych lub suboptymalnych dawek cytostatyków lub/i napromieniania lub/i realizację świadczeń medycznych przez niewystarczającą liczbę osób z odpowiednio wyszkolonej kadry, często przy udziale nieodpowiedniej infrastruktury oraz sprzętu i aparatury medycznej. Narodowy Fundusz Zdrowia nie posiada narzędzi ani uprawnień, aby ingerować w powyższy stan rzeczy, i finansuje w 100\% wszystkie świadczenia (procedury) fakturowane przez świadczeniodawcę - w tym świadczenia zbędne lub niewłaściwie zrealizowane.

Powyższe przesłanki wskazują na konieczność standaryzacji świadczeń realizowanych ze środków publicznych w zakresie diagnostyki i leczenia chorych na nowotwory. Miałyby one za zadanie wsparcie lekarzy w osiąganiu najwyższej skuteczności diagnostyczno-terapeutycznej w określonych typach i stopniach zaawansowania nowotworów, a narodowemu płatnikowi pozwoliłyby na zachowanie wysokiej efektywności ekonomicznej.

Standardy można postrzegać jako: 1) wytyczne (zalecenia) postępowania klinicznego tworzone i okresowo aktualizowane przez towarzystwa naukowe w określonych dziedzinach (specjalizacjach) oraz 2) protokoły postępowania (algorytmy) tworzone na poziomie poszczególnych placówek medycznych lub ich grup, które są zwykle mniej ogólne niż zalecenia i zawierają mniej wariantów postępowania. Lekarz powinien mieć prawo i możliwość odstąpienia od zaleceń i algorytmów, jednak w każdym przypadku powinien też uzasadnić powody takiego postępowania. Taka presja pozwala na upowszechnienie optymalnego postępowania w określonych sytuacjach klinicznych oraz umożliwia 
płatnikowi wprowadzenie jednolitych zasad finansowania i egzekucji określonej pragmatyki diagnostyczno-leczniczej dla wszystkich świadczeniodawców, bez względu na stopień referencyjności, organ tworzący czy właścicielski podmiotu leczniczego.

Medycyna specjalistyczna w Polsce, w tym onkologia i hematologia, mają długą tradycję tworzenia standardów postępowania diagnostyczno-leczniczego, między innymi poprzez publikowanie zaleceń klinicznych, skryptów i podręczników oraz zasad medycznych [8-10]. Obecnie standardy, jako obligatoryjne do stosowania i funkcjonujące $w$ formie rozporządzenia ministra zdrowia, dotyczą jedynie anestezjologii i intensywnej terapii. Inne zaczynają być publikowane na stronach internetowych NFZ jako zalecane do przestrzegania przez świadczeniodawców, na przykład u pacjentów z przewlekłą obturacyjną chorobą płuc. Jeszcze inne dotyczą „Medycznych zasad pobierania krwi, oddzielania jej składników i wydawania obowiązujących w jednostkach organizacyjnych publicznej służby krwi", które — zgodnie z pkt. 12 art. 25 ustawy o publicznej służbie krwi (DzU z 1997, nr 106, poz. 681 z późn. zm.) — należą do zadań IHT [9]. Na mocy tej ustawy Instytut jest zobowiązany opracowywać i aktualizować, także z udziałem ekspertów zewnętrznych, wyżej wymienione zasady medyczne, które - choć niebędące prawem - są traktowane jako obowiązujące w jednostkach publicznej służby krwi; przed wejściem w życie wymagają pozytywnej opinii Krajowej Rady ds. Krwiodawstwa i Krwiolecznictwa i akceptacji ministra zdrowia. Koszty z tym związane są w całości pokrywane z dotacji Ministerstwa Zdrowia, dlatego "Medyczne zasady..." w formie podręcznika są przekazywane nieodpłatnie wszystkim jednostkom publicznej służby krwi, w tym centrom krwiodawstwa i krwiolecznictwa, które przekazująje wszystkim swoim oddziałom terenowym zlokalizowanym w podmiotach leczniczych oraz pracowniom serologicznym i bankom krwi, nad którymi prowadzą nadzór merytoryczny.

Obecnie trwają prace legislacyjne, które przewidują wydawanie „Medycznych zasad..." w formie komunikatu ministra zdrowia, a nie rozporządzenia. Komunikat ministra zdrowia wydaje się właściwym kompromisem, albowiem łatwiej wprowadzić zmiany w jego treści niż w przypadku rozporządzenia, a jednocześnie jest on czymś więcej niż tylko zaleceniem. Podobne rozwiązanie prawno-legislacyjne można zastosować wobec publikowania wytycznych (algorytmów) postępowania diagnostyczno-leczniczego u chorych na nowotwory jako obowiązujące we wszystkich podmiotach leczniczych, które realizują świadczenia ze środków publicznych NFZ. Podstawą jego sformułowania powinny być okresowo aktualizowane zalecenia diagnostyczno-lecznicze przygotowywane przez odpowiednie towarzystwa naukowe [10]. Analogicznie do rozwiązań przyjętych dla publicznej służby krwi podmiotami odpowiedzialnymi za koordynację i właściwą realizację tego przedsięwzięcia po- winny być $\mathrm{NIOH}$ wraz z $\mathrm{KROH}$ - jako podmioty podległe bezpośrednio ministrowi zdrowia [1-3].

\section{Monitorowanie jakości postępowania diagnostyczno-leczniczego}

Wdrożenie w życie jednolitych zasad postępowania diagnostyczno-leczniczego powinno się stać podstawą opracowania wskaźników monitorowania jakości tego postępowania, które powinny być rutynowym elementem systemu informacyjnego ochrony zdrowia. W monitorowaniu niektórych wskaźników można będzie wykorzystać dane rozliczeniowe NFZ, natomiast inne będą wymagały osobnego systemu sprawozdawczego, obejmującego sprawozdawanie zdarzeń i danych koniecznych do pełnej oceny jakości procesu diagnostyczno-terapeutycznego w danym ośrodku. Koniecznym wydaje się utworzenie krajowego rejestru częstości stosowania i skuteczności (przeżycia całkowite, wyleczenie, powikłania) wdrażanych metod diagnostyczno-terapeutycznych w ośrodkach realizujących świadczenia onkologiczne ze środków publicznych wraz z oceną dostępności do wyżej wymienionych w poszczególnych regionach i województwach w kraju oraz sprawozdawaniem wskaźników oceny jakości opieki w kontekście przestrzegania zasad postępowania diagnostyczno-leczniczego. Taki rejestr można utworzyć w oparciu o doświadczenia, a nawet zasoby informatyczne już istniejącego Krajowego Rejestru Zachorowań na Nowotwory i rejestry wojewódzkie.

Parametrami podlegającymi ocenie byłyby przede wszystkim wskaźniki struktury danego podmiotu leczniczego, w tym posiadane warunki lokalowe, sprzętowe, aparaturowe, kadry specjalistyczne, organizacyjne warunki pracy itp. Wskaźniki jakości struktury są pojęciami statycznymi wskazującymi na potencjał placówki, ale niekoniecznie na skuteczność jego wykorzystania. Nie wynika z nich odpowiedź na pytanie, w jakim stopniu i czy w ogóle określone wskaźniki faktycznie wpływają na poziom jakości udzielanych świadczeń medycznych. Ich koniecznym uzupełnieniem stają się wskaźniki jakości procesu definiowane przez obowiązujące procedury składające się na proces diagnostyczny i leczniczy. Wraz ze wskaźnikami jakości wyniku, czyli parametrami odnoszącymi się do skutków tych procesów (uzyskiwany efekt zdrowotny i działania niepożądane), wszystkie te wskaźniki należy uznać za niezbędny punkt wyjścia w dążeniu do wysokiej jakości usług, ale także jako bardzo użyteczne narzędzia służące kwalifikacji podmiotu leczniczego do określonego poziomu referencyjności i zakresu kompetencji w systemie opieki onkologicznej.

\section{Referencyjność i zakres kompetencji podmiotów leczniczych w systemie opieki onkologicznej}

Powyższe przesłanki wskazują na konieczność nie tylko standaryzacji i monitorowania jakości świadczeń diagnostyczno-leczniczych, ale także wypracowania zasad re- 
ferencyjności podmiotów leczniczych w systemie opieki onkologicznej. Jako referencyjność rozumie się potencjał wykonawczy świadczeniodawcy, uwzględniający w szczególności liczbę i kwalifikację personelu medycznego, wyposażenie w sprzęt i aparaturę medyczną oraz możliwości diagnostyczno-terapeutyczne w określonej dziedzinie medycyny, zapewniające łącznie jakość i bezpieczeństwo udzielanych świadczeń. Dlatego referencyjność powinna obejmować wszystkie podmioty lecznicze ubiegające się o kontrakt onkologiczny ze środków publicznych.

Z praktycznego punktu widzenia i ze względu na rzeczywiste potrzeby, a także z powodów historycznych proponuje się jej 3-stopniowy podział na:

I - podmioty lecznicze realizujące świadczenia onkologiczne wyłącznie w AOS (tab. I);

II - podmioty lecznicze niespełniające wymagań dla kryteriów stopnia III oraz I i realizujące świadczenia onkologiczne w AOS oraz w trybie wyłącznie jednodniowym z zakresu chemioterapii i/lub chirurgii onkologicznej i/lub radioterapii (tab. IIA, B);

IIIA — podmioty lecznicze spełniające wymagania dla IIIC, ale tylko dla określonego typu nowotworu (tab. IIIA);

IIIB - podmioty lecznicze spełniające wymagania dla IIIC, ale tylko w odniesieniu do wybranych typów nowotworów (tab. IIIB);

IIIC - podmioty lecznicze realizujące wszystkie procedury diagnostyczne i lecznicze w odniesieniu do wszystkich typów nowotworów i stopni ich zaawansowania (tab. IIIC).

W obrębie danego stopnia referencyjności należy także określić zakres kompetencji podmiotu leczniczego do rozpoznawania i leczenia określonych typów nowotworów, z podaniem minimalnej liczby świadczeń do wykonania w danym okresie sprawozdawczym, aby mogły być finansowane ze środków publicznych NFZ.

\section{Audyt dotyczący przyznawania poziomów referencyjności i zakresów kompetencji podmiotom leczniczym udzielającym świadczeń onkologicznych ze środków publicznych}

Referencyjność i zakres kompetencji podmiotów leczniczych nie może być uznaniowa, a jakość realizowanych w nich świadczeń deklarowana - zamiast tego obie powinny być certyfikowane i okresowo audytowane. Celem audytów jest ocena wyposażenia i funkcjonowania danej jednostki pod względem wdrożenia i przestrzegania zasad postępowania diagnostyczno-leczniczego, obowiązujących procedur i przepisów prawnych. Audytowi powinny podlegać wcześniej wspomniane jakościowe wskaźniki struktury i procesów podmiotu leczniczego wnioskującego o audyt (załącznik 1). Audyt powinien być przeprowadzony przez ekspertów KROH i przy współudziale ośrodka akredytacji Centrum Monitorowania Jakości (CMJ).
Referencyjność i zakresy kompetencji powinny się zmieniać zależnie od potrzeb zdrowotnych w danym regionie (województwie) i potencjału wykonawczego ośrodka wnioskującego o nadanie określonego poziomu referencyjności i zakresu kompetencji. Dlatego powstawanie nowych podmiotów leczniczych i/lub wnioskowanie o audyt poziomu referencyjności i/lub zakresu kompetencji powinny być uzgodnioną inicjatywą lokalnych władz samorządowych i organu tworzącego dany podmiot leczniczy, z uwzględnieniem wcześniejszego uzyskania promesy pokrycia finansowego nowego zakresu świadczeń medycznych przez wojewódzki oddział NFZ i pozytywnej opinii $\mathrm{KROH}$.

Ze względu na istotne znaczenie i konsekwencje takiego audytu sposób jego przeprowadzania powinien mieć rangę rozporządzenia ministra zdrowia, na zasadach podobnych do certyfikacji ośrodków aplikujących o przyznanie uprawnień w zakresie pobierania, przechowywania i przeszczepienia komórek, tkanek i narządów przewidzianych ustawą transplantacyjną lub pobierania krwi, oddzielania jej składników i wydawania wynikających z ustawy o publicznej służbie krwi. Założenia do projektu takiego rozporządzenia przedstawiono w załączniku 2.

Należy podkreślić, że przeprowadzanie audytów poziomu referencyjności i zakresu kompetencji nie wymaga wydatkowania istotnych środków z budżetu państwa. Finansowanie $\mathrm{KROH}$ powinno się odbywać w trybie określonym dla innych krajowych rad działających przy ministrze zdrowia, w tym Krajowej Rady Transplantacyjnej czy Krajowej Rady ds. Krwiodawstwa i Krwiolecznictwa. W tym wypadku finansowanie dotyczy wyłącznie pokrycia kosztów podróży i ewentualnego zakwaterowania członków Rady. Koszty przeprowadzania audytu, w tym koszty podróży i zakwaterowania członków zespołu ekspertów audytujących podmiot leczniczy, należy przypisać podmiotowi, który będzie występował o przeprowadzenie audytu. Statutowe zadania o charakterze państwowym - tożsame dla CO-I oraz IHT i przewidziane projektem przedmiotowego rozporządzenia (załącznik 2) - uzasadniają konsolidację obu Instytutów w NIOH o statusie Państwowego Instytutu Badawczego (PIB) i również nie wymagają dodatkowych nakładów finansowych w formie dotacji z budżetu państwa, co szczegółowo omówiono w poprzedniej publikacji [1-3].

\section{Finansowanie świadczeń medycznych w zakresie onkologii w oparciu o poziomy referencyjności i zakresy kompetencji podmiotów leczniczych}

Podstawową zasadą w aspekcie obecnych uwarunkowań ekonomiczno-finansowych jest zwiększenie efektywności alokacji zasobów poprzez analizę kosztów i korzyści z uwzględnieniem elementu dostępności do świadczeń oraz jakości udzielanych usług zdrowotnych. Niezbędna jest w tym celu ocena ekonomiczna dostępnych technologii 
Tabela I. Przykład ośrodka o poziomie referencyjności I (ambulatoryjna opieka specjalistyczna)

\begin{tabular}{|c|c|c|c|c|c|c|c|c|c|c|}
\hline $\begin{array}{lr}\begin{array}{r}\text { Typy } \\
\text { Zakresy } \\
\text { swiadczeń }\end{array} \text { nowotworów } \\
\end{array}$ & $\begin{array}{c}\text { Głowa/ } \\
\text { /szyja }\end{array}$ & Płuca & Pierś & $\begin{array}{c}\text { Przewód } \\
\text { pokarmowy }\end{array}$ & Ginekologiczne & Urologiczne & Endokrynne & OUN & $\begin{array}{l}\text { Układu } \\
\text { chłonnego }\end{array}$ & $\begin{array}{l}\text { Układu } \\
\text { krwiotwórczego }\end{array}$ \\
\hline \multicolumn{11}{|l|}{ Profilaktyka pierwotna } \\
\hline \multicolumn{11}{|l|}{ Profilaktyka wtórna } \\
\hline \multicolumn{11}{|l|}{ Rejestr zachorowań } \\
\hline \multicolumn{11}{|l|}{$\begin{array}{l}\text { Diagnostyka patologiczno- } \\
\text {-cytogenetyczno-molekularna }\end{array}$} \\
\hline \multicolumn{11}{|l|}{ Chirurgia onkologiczna } \\
\hline \multicolumn{11}{|l|}{ Chemioterapia } \\
\hline \multicolumn{11}{|l|}{ Radioterapia } \\
\hline \multicolumn{11}{|l|}{ Psychoonkologia } \\
\hline \multicolumn{11}{|l|}{ Rehabilitacja } \\
\hline \multicolumn{11}{|l|}{ Opieka paliatywna } \\
\hline \multicolumn{11}{|l|}{ OIOM } \\
\hline \multicolumn{11}{|l|}{$\begin{array}{l}\text { Transplantacje komórek } \\
\text { krwiotwórczych }\end{array}$} \\
\hline $\begin{array}{l}\text { Ambulatoryjna opieka } \\
\text { specjalistyczna }\end{array}$ & $x$ & $x$ & $x$ & $x$ & $x$ & $x$ & $x$ & $x$ & $x$ & $x$ \\
\hline
\end{tabular}

OUN — ośrodkowy układ nerwowy

Tabela IIA. Przykład ośrodka o poziomie referencyjności II (centrum onkologii)

\begin{tabular}{|c|c|c|c|c|c|c|c|c|c|c|}
\hline $\begin{array}{lr}\text { Zakresy } \\
\text { swiadczeń }\end{array} \quad \begin{array}{r}\text { Typy } \\
\text { nowowtworów }\end{array}$ & $\begin{array}{l}\text { Glowa/ } \\
\text { /szyja }\end{array}$ & Płuca & Pierśs & $\begin{array}{c}\text { Przewód } \\
\text { pokarmowy }\end{array}$ & Ginekologiczne & Urologiczne & Endokrynne & OUN & $\begin{array}{c}\text { Układu } \\
\text { chłonnego }\end{array}$ & $\begin{array}{c}\text { Układu } \\
\text { krwiotwórczego }\end{array}$ \\
\hline \multicolumn{11}{|l|}{ Profilaktyka pierwotna } \\
\hline \multicolumn{11}{|l|}{ Profilaktyka wtórna } \\
\hline \multicolumn{11}{|l|}{ Rejestr zachorowań } \\
\hline $\begin{array}{l}\text { Diagnostyka patologiczno- } \\
\text {-cytogenetyczno-molekularna }\end{array}$ & & $x$ & $x$ & $x$ & $x$ & $x$ & $x$ & & $x$ & \\
\hline Chirurgia onkologiczna & & $x$ & $x$ & $x$ & $x$ & $x$ & $x$ & & $x$ & \\
\hline Chemioterapia & & $x$ & $x$ & $x$ & $x$ & $x$ & $x$ & & $x$ & \\
\hline \multicolumn{11}{|l|}{ Radioterapia } \\
\hline Psychoonkologia & & $x$ & $x$ & $x$ & $x$ & $x$ & $x$ & & $x$ & \\
\hline \multicolumn{11}{|l|}{ Rehabilitacja } \\
\hline \multicolumn{11}{|l|}{ Opieka paliatywna } \\
\hline \multicolumn{11}{|l|}{ OIOM } \\
\hline \multicolumn{11}{|l|}{$\begin{array}{l}\text { Transplantacje komórek } \\
\text { krwiotwórczych }\end{array}$} \\
\hline $\begin{array}{l}\text { Ambulatoryjna opieka } \\
\text { specjalistyczna }\end{array}$ & & $x$ & $x$ & $x$ & $x$ & $x$ & $x$ & & $x$ & \\
\hline
\end{tabular}

OUN — ośrodkowy układ nerwowy

Tabela IIB. Przykład ośrodka o poziomie referencyjności ll (centrum doskonałości)

\begin{tabular}{|c|c|c|c|c|c|c|c|c|c|c|}
\hline $\begin{array}{lr}\text { Zakresy } \\
\text { swiadczeń }\end{array}$ & $\begin{array}{l}\text { Głowa/ } \\
\text { /szyja }\end{array}$ & Płuca & Pierśs & $\begin{array}{l}\text { Przewód } \\
\text { pokarmowy }\end{array}$ & Ginekologiczne & Urologiczne & Endokrynne & OUN & $\begin{array}{l}\text { Układu } \\
\text { chłonnego }\end{array}$ & $\begin{array}{c}\text { Układu } \\
\text { krwiotwórczego }\end{array}$ \\
\hline \multicolumn{11}{|l|}{\begin{tabular}{|l|} 
Profilaktyka pierwotna \\
\end{tabular}} \\
\hline \multicolumn{11}{|l|}{ Profilaktyka wtórna } \\
\hline \multicolumn{11}{|l|}{ Rejestr zachorowań } \\
\hline \multicolumn{11}{|l|}{$\begin{array}{l}\text { Diagnostyka patologiczno- } \\
\text {-cytogenetyczno-molekularna }\end{array}$} \\
\hline \multicolumn{11}{|l|}{ Chirurgia onkologiczna } \\
\hline \multicolumn{11}{|l|}{ Chemioterapia } \\
\hline Radioterapia & $\times$ & $\times$ & $\times$ & $\times$ & $x$ & $\times$ & $\times$ & $\times$ & $\times$ & $\times$ \\
\hline \multicolumn{11}{|l|}{ Psychoonkologia } \\
\hline \multicolumn{11}{|l|}{ Rehabilitacja } \\
\hline \multicolumn{11}{|l|}{ Opieka paliatywna } \\
\hline \multicolumn{11}{|l|}{ OIOM } \\
\hline \multicolumn{11}{|l|}{$\begin{array}{l}\text { Transplantacje komórek } \\
\text { krwiotwórczych }\end{array}$} \\
\hline $\begin{array}{l}\text { Ambulatoryjna opieka } \\
\text { specjalistyczna }\end{array}$ & & & & & & & & & & \\
\hline
\end{tabular}

OUN — ośrodkowy układ nerwowy 
Tabela IIIA. Przykład ośrodka o poziomie referencyjności IIIA (centrum kompetencji)

\begin{tabular}{|c|c|c|c|c|c|c|c|c|c|c|}
\hline $\begin{array}{lr}\begin{array}{l}\text { Zakresy } \\
\text { swiadczeń }\end{array} \text { nowotworów } \\
\text { Typy }\end{array}$ & $\begin{array}{l}\text { Glowa/ } \\
\text { /szyja }\end{array}$ & Płuca & Pierśs & $\begin{array}{l}\text { Przewód } \\
\text { pokarmowy }\end{array}$ & Ginekologiczne & Urologiczne & Endokrynne & OUN & $\begin{array}{l}\text { Układu } \\
\text { chłonnego }\end{array}$ & $\begin{array}{c}\text { Układu } \\
\text { krwiotwórczego }\end{array}$ \\
\hline Profilaktyka pierwotna & & & $x$ & & & & & & & \\
\hline Profilaktyka wtórna & & & $x$ & & & & & & & \\
\hline Rejestr zachorowań & & & $x$ & & & & & & & \\
\hline $\begin{array}{l}\text { Diagnostyka patologiczno- } \\
\text {-cytogenetyczno-molekularna }\end{array}$ & & & $x$ & & & & & & & \\
\hline Chirurgia onkologiczna & & & $x$ & & & & & & & \\
\hline Chemioterapia & & & $x$ & & & & & & & \\
\hline Radioterapia & & & $x$ & & & & & & & \\
\hline Psychoonkologia & & & $x$ & & & & & & & \\
\hline Rehabilitacja & & & $x$ & & & & & & & \\
\hline Opieka paliatywna & & & $x$ & & & & & & & \\
\hline OIOM & & & $x$ & & & & & & & \\
\hline $\begin{array}{l}\text { Transplantacje komórek } \\
\text { krwiotwórczych }\end{array}$ & & & $x$ & & & & & & & \\
\hline $\begin{array}{l}\text { Ambulatoryjna opieka } \\
\text { specjalistyczna }\end{array}$ & & & $x$ & & & & & & & \\
\hline
\end{tabular}

OUN — ośrodkowy układ nerwowy

Tabela IIIB. Przykład ośrodka o poziomie referencyjności IIIIB (wielospecjalistyczne centrum onkologii)

\begin{tabular}{|c|c|c|c|c|c|c|c|c|c|c|}
\hline $\begin{array}{lr}\text { Zakresy } & \begin{array}{r}\text { Typy } \\
\text { świadczeń }\end{array} \text { nowotworów } \\
\end{array}$ & $\begin{array}{l}\text { Głowa/ } \\
\text { /szyja }\end{array}$ & Płuca & Pierś & $\begin{array}{l}\text { Przewód } \\
\text { pokarmowy }\end{array}$ & Ginekologiczne & Urologiczne & Endokrynne & OUN & $\begin{array}{c}\text { Układu } \\
\text { chłonnego }\end{array}$ & $\begin{array}{c}\text { Układu } \\
\text { krwiotwórczego }\end{array}$ \\
\hline Profilaktyka pierwotna & & $x$ & $x$ & $x$ & $x$ & $x$ & & & & \\
\hline Profilaktyka wtórna & & $x$ & $x$ & $x$ & $x$ & $x$ & & & & \\
\hline Rejestr zachorowań & & $x$ & $x$ & $x$ & $x$ & $x$ & & & & \\
\hline $\begin{array}{l}\text { Diagnostyka patologiczno- } \\
\text {-cytogenetyczno-molekularna }\end{array}$ & & $x$ & $x$ & $x$ & $x$ & $x$ & & & & \\
\hline Chirurgia onkologiczna & & $x$ & $x$ & $x$ & $x$ & $x$ & & & & \\
\hline Chemioterapia & & $x$ & $x$ & $x$ & $x$ & $x$ & & & & \\
\hline Radioterapia & & $x$ & $x$ & $x$ & $x$ & $x$ & & & & \\
\hline Psychoonkologia & & $x$ & $x$ & $x$ & $x$ & $x$ & & & & \\
\hline Rehabilitacja & & $x$ & $x$ & $x$ & $x$ & $x$ & & & & \\
\hline Opieka paliatywna & & $x$ & $x$ & $x$ & $x$ & $x$ & & & & \\
\hline OIOM & & $x$ & $x$ & $x$ & $x$ & $x$ & & & & \\
\hline $\begin{array}{l}\text { Transplantacje komórek } \\
\text { krwiotwórczych }\end{array}$ & & $x$ & $x$ & $x$ & $x$ & $x$ & & & & \\
\hline $\begin{array}{l}\text { Ambulatoryjna opieka } \\
\text { specjalistyczna }\end{array}$ & & $x$ & $x$ & $x$ & $x$ & $x$ & & & & \\
\hline
\end{tabular}

OUN — ośrodkowy układ nerwowy

Tabela IIIC. Przykład ośrodka o poziomie referencyjności IIIC (pełnoprofilowe wielospecjalistyczne centrum onkologii)

\begin{tabular}{|c|c|c|c|c|c|c|c|c|c|c|}
\hline $\begin{array}{lr}\begin{array}{r}\text { Typy } \\
\text { Zakresy } \\
\text { swwiadczeń }\end{array} & \text { nowotworów } \\
\end{array}$ & $\begin{array}{l}\text { Głowa/ } \\
\text { /szyja }\end{array}$ & Płuca & Pierś & $\begin{array}{l}\text { Przewód } \\
\text { pokarmowy }\end{array}$ & Ginekologiczne & Urologiczne & Endokrynne & OUN & $\begin{array}{l}\text { Układu } \\
\text { chłonnego }\end{array}$ & $\begin{array}{c}\text { Układu } \\
\text { krwiotwórczego }\end{array}$ \\
\hline Profilaktyka pierwotna & $x$ & $\times$ & $x$ & $x$ & $x$ & $\times$ & $x$ & $x$ & $x$ & $x$ \\
\hline Profilaktyka wtórna & $x$ & $x$ & $x$ & $x$ & $x$ & $x$ & $x$ & $x$ & $x$ & $x$ \\
\hline Rejestr zachorowań & $x$ & $x$ & $x$ & $x$ & $x$ & $x$ & $x$ & $x$ & $x$ & $x$ \\
\hline $\begin{array}{l}\text { Diagnostyka patologiczno- } \\
\text {-cytogenetyczno-molekularna }\end{array}$ & $x$ & $x$ & $x$ & $x$ & $x$ & $x$ & $x$ & $x$ & $x$ & $x$ \\
\hline Chirurgia onkologiczna & $x$ & $x$ & $x$ & $x$ & $x$ & $x$ & $x$ & $x$ & $x$ & $x$ \\
\hline Chemioterapia & $x$ & $x$ & $x$ & $x$ & $x$ & $x$ & $x$ & $x$ & $x$ & $x$ \\
\hline Radioterapia & $x$ & $x$ & $x$ & $x$ & $x$ & $x$ & $x$ & $x$ & $x$ & $x$ \\
\hline Psychoonkologia & $x$ & $x$ & $x$ & $x$ & $x$ & $x$ & $x$ & $x$ & $x$ & $x$ \\
\hline Rehabilitacja & $x$ & $x$ & $x$ & $x$ & $x$ & $x$ & $x$ & $x$ & $x$ & $x$ \\
\hline Opieka paliatywna & $x$ & $x$ & $x$ & $x$ & $x$ & $x$ & $x$ & $x$ & $x$ & $x$ \\
\hline OIOM & $x$ & $x$ & $x$ & $x$ & $x$ & $x$ & $x$ & $x$ & $x$ & $x$ \\
\hline $\begin{array}{l}\text { Transplantacje komórek } \\
\text { krwiotwórczych }\end{array}$ & $x$ & $x$ & $x$ & $x$ & $x$ & $x$ & $x$ & $x$ & $x$ & $x$ \\
\hline $\begin{array}{l}\text { Ambulatoryjna opieka } \\
\text { specjalistyczna }\end{array}$ & $x$ & $x$ & $x$ & $x$ & $x$ & $x$ & $x$ & $\times$ & $x$ & $x$ \\
\hline
\end{tabular}

OUN — ośrodkowy układ nerwowy 
medycznych w powiązaniu z wynikami klinicznymi i zdrowotnymi. Należy zaznaczyć, że ekonomiczna efektywność określana przez najwyższą wartość stosunku efektu do nakładu nie może być oddzielona od skutków zdrowotnych. Dlatego wydaje się, że celowym działaniem jest kierowanie się zasadami ekonomii normatywnej koncentrującej się na tworzeniu procedur i realizacji świadczeń, które - poprzez porównanie korzyści i kosztów — pozwolą na ocenę celowości działań medycznych.

Należy podkreślić, że istotnym problem finansowania świadczeń w ochronie zdrowia w Polsce jest niewłaściwa alokacja finansowych środków publicznych, czyli problem finansowania opieki zdrowotnej niezgodnie z zasadami racjonalnego gospodarowania. Mając na uwadze racjonalne gospodarowanie, należy brać pod uwagę, że jest ono związane $z$ istnieniem ograniczonych zasobów kadr specjalistycznych, aparatury i sprzętu medycznego, a także środków finansowych.

Efektywność dostępnych zasobów można zwiększyć poprzez zróżnicowaną wycenę świadczeń onkologicznych realizowanych w podmiotach leczniczych o różnym poziomie referencyjności. Proces ten jest długotrwały, bo wymaga przeprowadzenia audytu we wszystkich podmiotach leczniczych, które dobrowolnie przystąpią do procesu audytowania, a także rozpoczęcia niezbędnego procesu legislacyjnego, na postawie którego będzie możliwe zróżnicowanie finansowania świadczeń. Należy jednak podkreślić, że takie rozwiązanie nie wymaga żadnych dodatkowych nakładów finansowych, a wyłącznie przesunięcia środków związanych ze zróżnicowaną wyceną świadczeń między podmiotami leczniczymi o różnym poziomie referencyjności.

Alternatywną metodą — zastosowaną niezależnie lub w połączeniu ze wskazaną uprzednio - jest uwolnienie limitów dla ośrodków zapewniających kompleksowe świadczenia diagnostyczne i lecznicze dla wszystkich lub tylko dla wybranych typów nowotworów. Ten proces jest możliwy do przeprowadzenia w krótszym czasie, choć wymaga zabezpieczenia dodatkowych środków finansowych. $\mathrm{Na}$ podstawie danych dostępnych w centrali NFZ - dotyczących realizacji zawartych umów oraz wykonania świadczeń ponad limit w podmiotach leczniczych o potencjalne referencyjności III - ich wstępną wartość można określić na 250-300 mln PLN rocznie.

Można również przyjąć wariant, zgodnie z którym po uwolnieniu wyżej wymienionych limitów należy jednoczasowo przystąpić do realizacji zróżnicowanej wyceny świadczeń dla ośrodków o określonym stopniu referencyjności, który — jak już wspomniano - wymaga zarówno nakładów czasowych i finansowych, jak i istotnych zmian legislacyjnych.

Przedstawione propozycje sposobu realizacji świadczeń w oparciu o różne poziomy referencyjności podmiotów leczniczych pozwolą nie tylko na racjonalne wykorzystanie środków finansowych w systemie opieki onkologicznej, ale stworzą także realną szansę na zwiększenie dostępności i poprawę jakości udzielanych świadczeń medycznych. Umożliwią również precyzyjną i obiektywną ocenę istniejącego potencjału zaspokojenia potrzeb zdrowotnych w zakresie diagnozowania i leczenia chorych na nowotwory w poszczególnych regionach kraju, a tym samym — ustalanie rzeczywistych map potrzeb zdrowotnych w skali całego kraju.

Z całą mocą należy podkreślić, że powszechne uwolnienie limitów w systemie opieki onkologicznej bez standaryzacji metod diagnostyczno-leczniczych czy uwzględnienia potencjału wykonawczego świadczeniodawcy, mierzonego poziomem referencyjności i zakresem kompetencji, nie tylko nie usprawni funkcjonowania systemu ani nie przyczyni się do skrócenia kolejek chorych oczekujących na realizację świadczeń, ale w krótkim czasie doprowadzi do niekontrolowanego (nielimitowanego) przepływu publicznych pieniędzy do świadczeniodawców realizujących najlepiej wyceniane procedury. Nie tylko nie przyniesie to społeczeństwu oczekiwanych korzyści zdrowotnych, ale dodatkowo uszczupli już niewystarczające środki na opiekę onkologiczną oraz ograniczy dostęp pacjenta z chorobą nowotworową do najbardziej potrzebnych i skutecznych metod w oparciu o skojarzone, wielodyscyplinarne i kompleksowe świadczenia diagnostyczno-lecznicze.

\section{Podsumowanie}

W obu pracach dotyczących najważniejszych z punktu widzenia pacjenta z chorobą nowotworową zmian w polskim systemie opieki onkologicznej przedstawiono rozwiązania organizacyjne konieczne do wprowadzenia, by uzyskać właściwą regulację rynku świadczeń onkologicznych realizowanych ze środków publicznych i tym samym poprawę ich dostępności, skuteczności i bezpieczeństwa. Prace prowadzone przez inne zespoły - w tym tak zwany Cancer Plan - dotyczą znacznie szerszego zakresu problemów i strategii rozwoju polskiej onkologii, w tym: profilaktyki, epidemiologii, badań przesiewowych, diagnostyki, leczenia, kształcenia przed- i podyplomowego oraz kształtowania świadomości onkologicznej i edukacji całego społeczeństwa. Nie jest niczym złym, że różne projekty powstają niezależnie od siebie, tym bardziej że często pracują w nich ci sami eksperci. Realizując tak duże przedsięwzięcie, jakim jest poprawa systemu opieki onkologicznej w Polsce, należy brać pod uwagę wszystkie propozycje, zwłaszcza że ich rozwiązania będą względem siebie w dużej mierze komplementarne.

Na przykład, w żadnym ze znanych projektów nie kwestionuje się potrzeby wprowadzenia regulacji rynku świadczeń onkologicznych i jej zasadniczych elementów, w tym standaryzacji postępowania diagnostyczno-leczniczego, referencyjności i zakresu kompetencji podmiotów leczniczych współpracujących ze sobą w sieci ośrodków onkologicznych, których czynnikiem pozycjonującym nie 
będzie organ tworzący czy struktura właścicielska, a jedynie faktycznie posiadany potencjał wykonawczy mierzony wewnętrznymi i zewnętrznymi systemami monitorowania jakości udzielanych świadczeń. Nikt nie podważa także potrzeby istnienia jednostek koordynujących i nadzorujących działania krajowej sieci onkologicznej stanowiących ważny głos opiniodawczy i opiniotwórczy dla Ministerstwa Zdrowia, rządu, parlamentu i NFZ w podejmowaniu ważnych i odpowiedzialnych decyzji służących poprawie sytuacji w polskiej onkologii i w pracach nad budowaniem racjonalnej i przemyślanej strategii rozwoju tej dziedziny medycyny. Wspólnym mianownikiem wszystkich proponowanych rozwiązań jest w końcu koordynacja opieki onkologicznej i skoncentrowanie jej działań na chorym w miejsce koncentracji świadczeniodawców i płatnika na procedurze. Cel ten jest możliwy do osiągnięcia nie tyle na drodze tworzenia nowych podmiotów, ile dzięki lepszej i bardziej efektywnej współpracy między już istniejącymi ośrodkami w krajowej sieci onkologicznej i innymi szpitalami oraz AOS i POZ, w tym na zasadach partnerstwa publiczno-prywatnego.

Przedstawione propozycje mogą stanowić podstawę do analizy wielu zagadnień związanych z funkcjonowaniem systemu opieki onkologicznej w Polsce, porównania doświadczeń innych krajów w tym zakresie i wypracowania optymalnych rozwiązań na przyszłość. Mogą także stanowić wskazówki dla grup roboczych skupionych wokół tak zwanego Cancer Planu i Ministerstwa Zdrowia, które przygotowują strategie dla polskiej onkologii i założenia do Narodowego Programu Zwalczania Chorób Nowotworowych na lata 2015-2024.

\section{Podziękowania}

Składam wyrazy podziękowania za merytoryczną i organizacyjną pomoc w przygotowaniu projektu prof. Maciejowi Krzakowskiemu - Konsultantowi Krajowemu ds. Onkologii, dr Beacie Jagielskiej — Konsultantowi Wojewódzkiemu ds. Onkologii dla województwa mazowieckiego, prof. Krzysztofowi Składowskiemu — Przewodniczącemu Polskiego Towarzystwa Radioterapii Onkologicznej, prof. Jackowi Fijuthowi — Przewodniczącemu Elektowi Polskiego Towarzystwa Onkologicznego, prof. Piotrowi Rutkowskie- mu — Przewodniczącemu Elektowi Polskiego Towarzystwa Chirurgii Onkologicznej, prof. Piotrowi Wysockiemu — Przewodniczącemu Elektowi Polskiego Towarzystwa Onkologii Klinicznej, dr Januszowi Mederowi - Przewodniczącemu Polskiej Unii Onkologii, prof. Jerzemu Hołowieckiemu - Przewodniczącemu Stowarzyszenia ds. Leczenia Białaczek u Dorosłych, prof. Sebastianowi Giebelowi — Przewodniczącemu Polskiej Grupy Badawczej Chłoniaków, a także dr. Zbigniewowi Pawłowiczowi — Przewodniczącemu Rady Dyrektorów Publicznych Wielospecjalistycznych Centrów Onkologii i pozostałym Sygnatariuszom tego porozumienia. Dziękuję także innym Pracownikom Centrum Onkologii — Instytutu im. Marii Skłodowskiej-Curie, a w szczególności profesorom Witoldowi Zatońskiemu, Janowi Walewskiemu, Jarosławowi Regule, Zbigniewowi Noweckiemu oraz Jerzemu Jakubowiczowi i Bogusławowi Maciejewskiemu.

Prof. dr hab. n. med. Krzysztof Warzocha

Instytut Hematologii i Transfuzjologii

ul. Indiry Gandhi 14, 02-776 Warszawa

e-mail:warzocha@ihit.waw.pl

\section{Piśmiennictwo}

1. Warzocha K. Narodowy Instytut Onkologii i Hematologii. Hematologia 2013; 4: 185-196.

2. Warzocha K. Narodowy Instytut Onkologii i Hematologii. Onkol Prakt Klin 2013; 9: 172-183.

3. Warzocha K. Narodowy Instytut Onkologii i Hematologii. Nowotwory 2013; 63: 357-367.

4. Kozierkiewicz A., Jassem J. Narodowe strategie zwalczania nowotworów: doświadczenia, struktura, dobre praktyki. Nowotwory 2013:63:368-374

5. Zatoński W.A. Powołanie Narodowego Instytutu Onkologii i Hematologii - warunek konieczny do skutecznej walki z rakiem w Polsce. Nowotwory 2013; 63: 375-381.

6. Krzakowski M. Narodowy Instytut Onkologii i Hematologii — głos w dyskusji. Onkol Prakt Klin 2013; 9: 184-185.

7. Kozierkiewicz A. Konsolidacja i integracja opieki zdrowotnej. Ministerstwo Zdrowia, Warszawa 2011.

8. Krzakowski M. Onkologia kliniczna - uwarunkowania jakości postępowania. Nowotwory 2010; 60: 453-455.

9. Łętowska M. (red.). Medyczne zasady pobierania krwi, oddzielania składników i wydawania, obowiazujace w jednostkach organizacyjnych publicznej służby krwi. Instytut Hematologii i Transfuzjologii, Warszawa 2011.

10. Krzakowski M., Warzocha K. (red.). Zalecenia postępowania diagnostyczno-terapeutycznego w nowotworach złośliwych - 2013 rok. Gdańsk: Via Medica, 2013. 
Przykładowe parametry audytowe dotyczące przyznawania stopni referencyjności i zakresów kompetencji podmiotom leczniczym udzielającym świadczeń onkologicznych ze środków publicznych

\section{Wyposażenie}

1. Radiologia/patologia w lokalizacji:

$\begin{array}{lll}\text { CT } & \text { tak } \square & \text { nie } \square \\ \text { MR } & \text { tak } \square & \text { nie } \square \\ \text { PET } & \text { tak } \square & \text { nie }\end{array}$

Scyntygrafia

RTG

badania histopatologiczne

śródoperacyjne wykonywane rutynowo

2. Radioterapia/brachyterapia:

liczba przyspieszaczy liniowych (ogółem)

z MLC

$z$ mMLC

z urządzeniem tracking

z urządzeniem gating

liczba bomb kobaltowych

liczba ortowoltowych aparatów rentgenowskich

liczba aparatów do radioterapii śródoperacyjnej

liczba aparatów do brachyterapii:

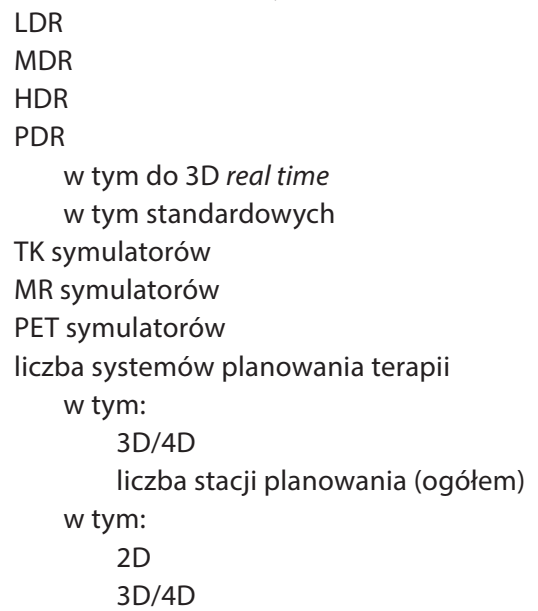

\section{Blok operacyjny:}

w strukturze organizacyjnej kliniki/oddziału chirurgii samodzielna jednostka organizacyjna

liczba sal operacyjnych

liczba stanowisk operacyjnych

liczba aparatów do znieczulania

system audio-video rejestracji operacji

system neuronawigacji

USG śródoperacyjne

ramię C-RTG

sprzęt do laparoskopii

sprzęt do HIPEC/ILP

sprzęt do elektrochemioterapii

4. Medycyna nuklearna:

liczba scyntygrafów

zamknięty oddział terapii izotopowej

pracownia porcjowania izotopów w lokalizacji

5. Pracownia endoskopii:

liczba kolonoskopów

liczba gastroskopów

liczba duodenoskopów

dostępność do świadczeń 24 godziny

\begin{tabular}{ll}
$\begin{array}{l}\operatorname{tak} \square \\
\operatorname{tak} \square\end{array}$ & nie $\square$ \\
\hline & nie $\square$ \\
\hline & \\
\hline $\operatorname{tak} \square$ & nie $\square$ \\
$\operatorname{tak} \square$ & nie $\square$ \\
$\operatorname{tak} \square$ & nie $\square$ \\
$\operatorname{tak} \square$ & nie $\square$ \\
$\operatorname{tak} \square$ & nie $\square$ \\
$\operatorname{tak} \square$ & nie $\square$ \\
$\operatorname{tak} \square$ & nie $\square$
\end{tabular}

Liczba urządzeń
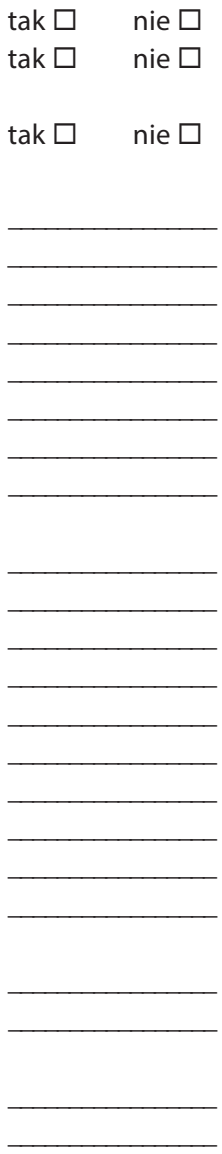

tak e $\square$

tak $\square \quad$ nie $\square$

tak $\square \quad$ nie $\square$

tak $\square \quad$ nie $\square$ 


\section{Kadra specjalistyczna}

1. Ogólna liczba specjalistów

chirurgów ogólnych

chirurgów onkologicznych

neurochirurgów

chirurgów innej specjalizacji (jakiej)

onkologia kliniczna

radioterapia onkologiczna

ginekologia onkologiczna

hematologia

transplantologia

fizyka:

- fizyka medyczna

- inspektor ochrony radiologicznej

inne specjalności (jakie)

2. Inni pracownicy medyczni:

ogółem

pielęgniarki onkologiczne

technicy elektrokardiologii

laboranci

sekretarki medyczne

informatycy

III. Personel: specjaliści w dziedzinach (podać liczbę):

1. Onkologii klinicznej (ogólem)

w tym zatrudnionych w ramach:

umowy o pracę na pełny etat:

kontraktu:

umowy zlecenia:

umowy o dzieło:

inne formy (podać jakie i liczbę zatrudnionych):

staż pracy od uzyskania specjalizacji z zakresu onkologii klinicznej:

$$
\begin{aligned}
& \text { poniżej } 5 \text { lat } \\
& \text { od } 5 \text { do } 10 \text { lat } \\
& \text { powyżej } 10 \text { lat }
\end{aligned}
$$

2. Chirurgii onkologicznej (ogólem)

w tym zatrudnionych w ramach:

umowy o pracę na pełny etat:

kontraktu:

umowy zlecenia:

umowy o dzieło:

inne formy (podać jakie i liczbę zatrudnionych):

staż pracy od uzyskania specjalizacji z zakresu chirurgii onkologicznej:

$$
\begin{aligned}
& \text { poniżej } 5 \text { lat } \\
& \text { od } 5 \text { do } 10 \text { lat }
\end{aligned}
$$$$
\text { powyżej } 10 \text { lat }
$$

3. Radioterapii (ogólem)

w tym zatrudnionych w ramach:

umowy o pracę na pełny etat:

kontraktu:

umowy zlecenia:

umowy o dzieło:

inne formy (podać jakie i liczbę zatrudnionych):

staż pracy od uzyskania specjalizacji z zakresu radioterapii:

poniżej 5 lat

od 5 do 10 lat

powyżej 10 lat 
4. Hematologii (ogólem)

w tym zatrudnionych w ramach:

umowy o pracę na pełny etat:

kontraktu:

umowy zlecenia:

umowy o dzieło:

inne formy (podać jakie i liczbę zatrudnionych):

staż pracy od uzyskania specjalizacji z zakresu hematologii:

poniżej 5 lat

od 5 do 10 lat

powyżej 10 lat

5. Chorób wewnętrznych (ogółem)

w tym zatrudnionych w ramach:

umowy o pracę na pełny etat:

kontraktu:

umowy zlecenia:

umowy o dzieło:

inne formy (podać jakie i liczbę zatrudnionych):

6. Ginekologii onkologicznej (ogółem)

w tym zatrudnionych w ramach:

umowy o pracę na pełny etat:

kontraktu:

umowy zlecenia:

umowy o dzieło:

inne formy (podać jakie i liczbę zatrudnionych):

7. Fizyki medycznej (ogółem)

w tym zatrudnionych w ramach:

umowy o pracę na pełny etat:

kontraktu:

umowy zlecenia:

umowy o dzieło:

inne formy (podać jakie i liczbę zatrudnionych):

- ze specjalizacją fizyka medyczna

- inspektor ochrony radiologicznej

8. Medycyny nuklearnej (ogółem)

w tym zatrudnionych w ramach:

umowy o pracę na pełny etat:

kontraktu:

umowy zlecenia:

umowy o dzieło:

inne formy (podać jakie i liczbę zatrudnionych):

9. Pielęgniarki (ogółem):

w tym zatrudnionych w ramach:

umowy o pracę, w tym liczba zatrudnionych na pełny etat:

kontraktu:

umowy zlecenia:

umowy o dzieło:

inne formy (podać jakie i liczbę zatrudnionych):

liczba pielęgniarek ze specjalizacją w zakresie:

- pielęgniarstwa onkologicznego

- pielęgniarstwa chirurgicznego

liczba pielęgniarek posiadająca dyplomy ukończenia

kursów/szkoleń w zakresie podawania cytostatyków

10. Farmaceuci (ogółem)

w tym zatrudnionych $w$ ramach:

umowy o pracę:

kontraktu:

umowy zlecenia:

umowy o dzieło:

inne formy (podać jakie i liczbę zatrudnionych): 


\section{Diagności laboratoryjni (ogółem)}

w tym zatrudnionych w ramach:

umowy o pracę:

kontraktu:

umowy zlecenia:

umowy o dzieło:

inne formy (podać jakie i liczbę zatrudnionych):

\section{Posiadane system(y) informatyczne (y):}

wewnątrz jednostek ośrodka

między jednostkami ośrodka

centrala obejmuje przekaz informacji:

- parametrycznych

- obrazowych

- opisowych

$\begin{array}{ll}\text { tak } \square & \text { nie } \square \\ \text { tak } \square & \text { nie } \square \\ \text { tak } \square & \text { nie } \square \\ \text { tak } \square & \text { nie } \square \\ \text { tak } \square & \text { nie } \square \\ & \\ \text { tak } \square & \text { nie } \square \\ \text { tak } \square & \text { nie } \square \\ \text { od ........... do ......... } \\ \text { tak } \square & \text { nie } \square \\ \text { tak } \square & \text { nie } \square \\ \text { tak } \square & \text { nie } \square\end{array}$

VI. Ewidencja danych medycznych:

archiwizacja dokumentacji medycznej:

- papierowa

- elektroniczna

- obie formy

systemy informatyczne:

- HIS (Hospital Information System)

- LIS (Laboratory Information System)

- RIS (Radiology Information System)

- PACS (Picture Archiving and Communication System)

- wymiana danych pomiędzy systemami

- część administracyjna (systemy klasy ERP)

$\begin{array}{ll}\operatorname{tak} \square & \text { nie } \square \\ \operatorname{tak} \square & \text { nie } \square \\ \operatorname{tak} \square & \text { nie } \square \\ \text { tak } \square & \text { nie } \square \\ \operatorname{tak} \square & \text { nie } \square \\ \operatorname{tak} \square & \text { nie } \square \\ \text { tak } \square & \text { nie } \square \\ \text { tak } \square & \text { nie } \square\end{array}$

VII. Rodzaj udzielanych świadczeń medycznych

1. Onkologia kliniczna

ICD-10 C50

ICD-10 C15-C26 (łącznie)

a szczegółowo:

C15

$\mathrm{C} 25$

$\mathrm{C} 20$

$\mathrm{C} 22$

raki neuroendokrynne

ICD-10 C43

ICD-10 C76-C80

ICD-10 C30-C39

2. Chemioterapia

ICD-10 C50

ICD-10 C15-C26 (łącznie)

a szczegółowo:

C15

$\mathrm{C} 20$

$\mathrm{C} 22$

C25

$\begin{array}{ll}\operatorname{tak} \square & \text { nie } \square \\ \operatorname{tak} \square & \text { nie } \square \\ \operatorname{tak} \square & \text { nie } \square \\ \text { tak } \square & \text { nie } \square \\ \operatorname{tak} \square & \text { nie } \square \\ \operatorname{tak} \square & \text { nie } \square \\ \operatorname{tak} \square & \text { nie } \square \\ \operatorname{tak} \square & \text { nie } \square \\ \operatorname{tak} \square & \text { nie } \square \\ \operatorname{tak} \square & \text { nie } \square \\ \operatorname{tak} \square & \text { nie } \square \\ \operatorname{tak} \square & \text { nie } \square \\ \operatorname{tak} \square & \text { nie } \square \\ \operatorname{tak} \square & \text { nie } \square \\ & \\ \operatorname{tak} \square & \text { nie } \square \\ \operatorname{tak} \square & \text { nie } \square \\ \operatorname{tak} \square & \text { nie } \square \\ \operatorname{tak} \square & \text { nie } \square\end{array}$


raki neuroendokrynne

tak $\square \quad$ nie $\square$

ICD-10 C40-C41

ICD-10 C43

ICD-10 C76-C80

ICD-10 C30-C39

3. Chirurgia onkologiczna

ICD-10 C50

ICD-10 C15-C26 (łącznie)

tak $\square$

tak $\square \quad$ nie $\square$

tak $\square \quad$ nie $\square$

tak $\square \quad$ nie $\square$

tak $\square \quad$ nie $\square$

tak $\square \quad$ nie $\square$

a szczegółowo:

C15

tak $\square$

nie $\square$

$\mathrm{C} 20$

C22

C25

raki neuroendokrynne

ICD-10 C40-C41

ICD-10 C43

ICD-10 C51-C57

tak $\square \quad$ nie $\square$

tak $\square \quad$ nie $\square$

tak $\square \quad$ nie $\square$

tak $\square \quad$ nie $\square$

tak $\square \quad$ nie $\square$

tak $\square \quad$ nie $\square$

tak $\square \quad$ nie $\square$

tak $\square \quad$ nie $\square$

tak $\square \quad$ nie $\square$

tak $\square \quad$ nie $\square$

tak $\square \quad$ nie $\square$

tak $\square \quad$ nie $\square$

tak $\square \quad$ nie $\square$

tak $\square \quad$ nie $\square$

tak $\square \quad$ nie $\square$

B. Teleradioterapia

ICD-10 C01-C14

ICD-10 C30-C32

ICD-10 C71

ICD-10 C20

ICD-10 C40-C41

ICD-10 C61

tak $\square \quad$ nie $\square$

tak $\square \quad$ nie $\square$

tak $\square \quad$ nie $\square$

tak $\square \quad$ nie $\square$

tak $\square \quad$ nie $\square$

tak $\square \quad$ nie $\square$

tak $\square \quad$ nie $\square$

5. Hematologia:

tak $\square \quad$ nie $\square$

tak $\square \quad$ nie $\square$

tak $\square \quad$ nie $\square$

tak $\square \quad$ nie $\square$

tak $\square \quad$ nie $\square$

tak $\square \quad$ nie $\square$

tak $\square \quad$ nie $\square$

tak $\square \quad$ nie $\square$

tak $\square \quad$ nie $\square$

tak $\square \quad$ nie $\square$

tak $\square \quad$ nie $\square$

tak $\square \quad$ nie $\square$

tak $\square \quad$ nie $\square$

tak $\square \quad$ nie $\square$

tak $\square \quad$ nie $\square$

tak $\square \quad$ nie $\square$

VIII. Tryb realizowania świadczeń ww. zakresie

1. Onkologia kliniczna:

ambulatoryjny:

hospitalizacja:

wszystkie ww.:

tak $\square \quad$ nie $\square$

tak $\square \quad$ nie $\square$

tak $\square \quad$ nie $\square$

2. Chemioterapia:

ambulatoryjny:

1-dniowy:

hospitalizacja:

tak $\square \quad$ nie $\square$

tak $\square \quad$ nie $\square$

wszystkie ww.:

tak $\square \quad$ nie $\square$

tak $\square \quad$ nie $\square$

3. Chirurgia onkologiczna:

ambulatoryjny:

tak $\square \quad$ nie $\square$

hospitalizacja:

tak $\square \quad$ nie $\square$

leczenie jednego dnia:

tak $\square \quad$ nie $\square$ 
4. Radioterapia:

ambulatoryjny:

hospitalizacja:

tak $\square \quad$ nie $\square$

wszystkie ww.:

tak $\square \quad$ nie $\square$

5. Hematologia

ambulatoryjny:

tak $\square$

nie $\square$

hospitalizacja:

transplantacja komórek krwiotwórczych:

tak $\square \quad$ nie $\square$

wszystkie ww.:

IX. Wykonywane procedury wspomagające świadczenia onkologiczne na terenie danego ośrodka (w lokalizacji)

1. Diagnostyczne

A. Badania laboratoryjne

Badania morfologii

Badania biochemiczne

tak $\square \quad$ nie $\square$

Badania markerów nowotworowych z krwi obwodowej

Badania mikrobiologiczne

Badania cytologiczne krwi i szpiku

Badania immunofenotypowe

Badania histopatologiczne

Badania cytogenetyczne

Badania molekularne

Badania zgodności tkankowej (HLA)

tak $\square \quad$ nie $\square$

tak $\square \quad$ nie $\square$

tak $\square \quad$ nie $\square$

tak $\square \quad$ nie $\square$

tak $\square \quad$ nie $\square$

tak $\square \quad$ nie $\square$

tak $\square \quad$ nie $\square$

tak $\square \quad$ nie $\square$

tak $\square \quad$ nie $\square$

B. Badania obrazowe

RTG

USG

tak $\square \quad$ nie $\square$

MR

TK

PET

Scyntygrafia

tak $\square \quad$ nie $\square$

tak $\square \quad$ nie $\square$

tak $\square \quad$ nie $\square$

tak $\square \quad$ nie $\square$

tak $\square \quad$ nie $\square$

2. Lecznicze:

Izba Przyjęć czynna 24 h/SOR

tak $\square \quad$ nie $\square$

OAIT

dializoterapia

tak $\square \quad$ nie $\square$

oddział leczenia paliatywnego

tak $\square \quad$ nie $\square$

pracownia serologii

bank krwi

tak $\square \quad$ nie $\square$

tak $\square \quad$ nie $\square$

psycholog

tak $\square \quad$ nie $\square$

w tym poradnia:

tak $\square \quad$ nie $\square$

zdrowia psychicznego

tak $\square \quad$ nie $\square$

genetyczna

tak $\square \quad$ nie $\square$

leczenia bólu

tak $\square \quad$ nie $\square$

poradnia/zakład profilaktyki realizujące świadczenia:

tak $\square \quad$ nie $\square$

profilaktyki raka piersi

tak $\square \quad$ nie $\square$

profilaktyki raka szyjki

tak $\square \quad$ nie $\square$

\section{Gospodarka lekami}

1. W podmiocie funkcjonuje komitet terapeutyczny:

tak $\square \quad$ nie $\square$

2. W skład komitetu terapeutycznego wchodzą specjaliści z zakresu:

$\square$ medycyny w liczbie

$\square$ farmacji w liczbie

$\square$ innych dziedzin w liczbie

3. Spotkania komitetu terapeutycznego odbywają się z częstotliwością:

$\square$ regularnie i nie rzadziej niż raz w miesiącu

$\square$ raz w roku

$\square 2$ razy w roku

4. W podmiocie ustalana jest szpitalna lista leków

tak $\square \quad$ nie $\square$ 
5. Zadania realizowane przez komitet terapeutyczny podmiotu:

\begin{tabular}{|l|l|l|}
\hline Wybór produktów do szpitalnej listy leków (SLL) & tak $\square$ & nie $\square$ \\
\hline Określenie trybów wprowadzania nowych produktów leczniczych do SLL i do terapii & tak $\square$ & nie $\square$ \\
\hline $\begin{array}{l}\text { Określenie sposobu uzyskiwania leków w trybie nagłym, spoza SLL oraz sprowadzanych } \\
\text { w trybie importu docelowego }\end{array}$ & tak $\square$ & nie $\square$ \\
\hline $\begin{array}{l}\text { Analiza i zatwierdzanie wniosków dotyczących wprowadzania i skreślania produktów leczniczych } \\
\text { z SLL }\end{array}$ & tak $\square$ & nie $\square$ \\
\hline $\begin{array}{l}\text { Kontrola planowania i wykorzystania produktów leczniczych w jednostkach organizacyjnych } \\
\text { podmiotu, ze szczególnym uwzględnieniem programów lekowych NFZ }\end{array}$ & tak $\square$ & nie $\square$ \\
\hline Ocena skuteczności i kosztów leczenia & tak $\square$ & nie $\square$ \\
\hline Zbieranie i analiza doniesień dotyczących działań niepożądanych produktów leczniczych & tak $\square$ & nie $\square$ \\
\hline $\begin{array}{l}\text { Analiza zgłaszanych i publikowanych doniesień na temat interakcji w fazie farmaceutycznej, } \\
\text { farmakokinetycznej i farmakodynamicznej produktów leczniczych }\end{array}$ & tak $\square$ & nie $\square$ \\
\hline Udział w opracowywaniu tematyki szkoleń dla personelu fachowego dotyczących farmakoterapii & tak $\square$ & nie $\square$ \\
\hline Ustalanie zasad kontroli gospodarki lekiem w jednostkach organizacyjnych podmiotu & tak $\square$ & nie $\square$ \\
\hline $\begin{array}{l}\text { Opiniowanie opisu produktów leczniczych do specyfikacji przetargowych oraz udział w pracach } \\
\text { komisji przetargowych }\end{array}$ & tak $\square$ & nie $\square$ \\
\hline
\end{tabular}

\section{Badania kliniczne zarejestrowane w CEBK realizowane w podmiocie medycznym}

Łączna liczba badań klinicznych:

Łączna liczba chorych zrekrutowanych:

Liczba badań klinicznych w danych jednostkach chorobowych wg kodów ICD-10:
ICD-10 C50
ICD-10 C15-C26
ICD-10 C40-C41
ICD-10 C43
ICD-10 C30-C39
ICD-10 C61

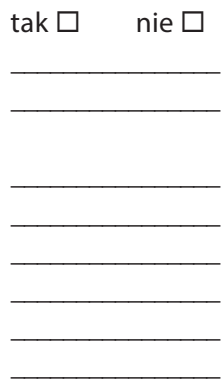

XII. Liczba i rodzaj wykonywanych procedur diagnostyczno-leczniczych
40.12 - wycięcie węzła wartowniczego (C-50)
40.12 - wycięcie węzła wartowniczego (C-43)
43.11 - przezskórne endoskopowe wytworzenie przetoki żołądkowej (PEG)
51.991 - wprowadzenie lub wymiana protezy dróg żółciowych
42.333 - endoskopowe wycięcie polipa przełyku
43.411 - endoskopowe wycięcie polipa żołądka
45.42 - endoskopowe wycięcie polipa jelita grubego

XIII. Liczba wykonanych zabiegów rekonstrukcyjnych w:
ICD-10 C50
ICD-10 C01-C14
ICD-10 C30-C32
ICD-10 C40-C41
ICD-10 C18-C20

XIV. Programy terapeutyczne (lekowe)

\begin{tabular}{|l|l|l|l|l|}
\hline Rodzaj programu & $\begin{array}{l}\text { Liczba leczonych } \\
\text { chorych (ogółem) }\end{array}$ & Tryb ambulatoryjny & Tryb jednodniowy & Hospitalizacja \\
\hline
\end{tabular}

\section{Leczenie powikłań /wg CTC v 3.0/}

Liczba chorych hospitalizowanych z powodu powikłań

1. i 2. stopień

3. i 4. stopień

Liczba chorych hospitalizowanych z powodu powikłań

ICD-10 C50

ICD-10 C30-39

ICD-10 C18-C20 


\section{Załącznik 2}

Projekt rozporządzenia ministra zdrowia o sposobie przeprowadzania audytów dotyczących przyznawania poziomu referencyjności i zakresu kompetencji podmiotom leczniczym udzielającym świadczeń w rodzaju ambulatoryjna opieka specjalistyczna/lecznictwo szpitalne, w zakresie chirurgii onkologicznej, onkologii klinicznej oraz radioterapii ze środków publicznych

\section{Rozdział 1}

\section{Przepisy ogólne}

Art. 1. Rozporządzenie określa zasady przeprowadzania audytów zewnętrznych w podmiotach leczniczych udzielających świadczeń w rodzaju ambulatoryjna opieka specjalistyczna/lecznictwo szpitalne w zakresie chirurgii onkologicznej, onkologii klinicznej oraz radioterapii.

Art. 2. Celem przeprowadzanych audytów zewnętrznych jest przyznanie poziomu referencyjności i zakresu kompetencji podmiotom leczniczym udzielającym świadczeń w zakresie chirurgii onkologicznej, onkologii klinicznej oraz radioterapii.

Art. 3. Podmiotami leczniczymi są podmioty lecznicze w rozumieniu ustawy o działalności leczniczej:

1) przedsiębiorcy w rozumieniu przepisów ustawy z dnia 2 lipca 2004 r. o swobodzie działalności gospodarczej (DzU z 2010 r. nr 220, poz. 1447, z późn. zm.) we wszelkich formach przewidzianych do wykonywania działalności gospodarczej, jeżeli ustawa nie stanowi inaczej;

2) samodzielne publiczne zakłady opieki zdrowotnej;

3) jednostki budżetowe, w tym państwowe jednostki budżetowe tworzone i nadzorowane przez ministra obrony narodowej, ministra właściwego do spraw wewnętrznych, ministra sprawiedliwości lub szefa agencji bezpieczeństwa wewnętrznego, posiadające w strukturze organizacyjnej ambulatorium, ambulatorium z izbą chorych lub lekarza podstawowej opieki zdrowotnej;

4) instytuty badawcze, o których mowa w art. 3 ustawy z dnia 30 kwietnia 2010 r. o instytutach badawczych (DzU nr 96, poz. 618 oraz z 2011 r. nr 112, poz. 654 i nr 185, poz. 1092);

5) fundacje i stowarzyszenia, których celem statutowym jest wykonywanie zadań w zakresie ochrony zdrowia i których statut dopuszcza prowadzenie działalności leczniczej;

5a) posiadające osobowość prawną jednostki organizacyjne stowarzyszeń, o których mowa w pkt. 5;

6) osoby prawne i jednostki organizacyjne działające na podstawie przepisów o stosunku Państwa do Kościoła Katolickiego w Rzeczypospolitej Polskiej, o stosunku Państwa do innych kościołów i związków wyznaniowych oraz o gwarancjach wolności sumienia i wyznania w zakresie, w jakim wykonują działalność leczniczą.

Art. 4. Rozporządzenie nie dotyczy audytów wewnętrznych przeprowadzanych na potrzeby jednostek wymieniowych wart. 3.

Art. 5. Użyte w rozporządzeniu określenia oznaczają:

1) dokumentacja medyczna - dokumentację medyczną, o której mowa w przepisach ustawy z dnia 6 listopada 2008 r. o prawach pacjenta i Rzeczniku Praw Pacjenta (DzU z 2012 r. poz. 159 i 742);

2) pacjent - pacjenta w rozumieniu ustawy z dnia 6 listopada 2008 r. o prawach pacjenta i Rzeczniku Praw Pacjenta (DzU. z 2012 r. poz. 159 i 742);

3) osoba wykonująca zawód medyczny — osobę uprawnioną na podstawie odrębnych przepisów do udzielania świadczeń zdrowotnych oraz osobę legitymującą się nabyciem fachowych kwalifikacji do udzielania świadczeń zdrowotnych w określonym zakresie lub w określonej dziedzinie medycyny;

4) podmiot leczniczy — podmiot wykonujący działalność leczniczą, o którym mowa w art. 3;

5) świadczenie zdrowotne — działania służące zachowaniu, ratowaniu, przywracaniu lub poprawie zdrowia oraz inne działania medyczne wynikające z procesu leczenia lub przepisów odrębnych regulujących zasady ich wykonywania;

6) świadczenie szpitalne - wykonywane całą dobę kompleksowe świadczenia zdrowotne polegające na diagnozowaniu, leczeniu, pielęgnacji i rehabilitacji, które nie mogą być realizowane w ramach innych stacjonarnych i całodobowych świadczeń zdrowotnych lub ambulatoryjnych świadczeń zdrowotnych; świadczeniami szpitalnymi są także świadczenia udzielane z zamiarem zakończenia ich udzielania w okresie nieprzekraczającym 24 godzin;

7) stacjonarne i całodobowe świadczenie zdrowotne inne niż świadczenie szpitalne — świadczenia opiekuńcze, pielęgnacyjne, paliatywne, hospicyjne, świadczenia z zakresu opieki długoterminowej, rehabilitacji leczniczej, leczenia uzależnień, psychiatrycznej opieki zdrowotnej oraz lecznictwa uzdrowiskowego, udzielane pacjentom, których stan zdrowia wymaga udzielania całodobowych lub całodziennych świadczeń zdrowotnych w odpowiednio urządzonych, stałych pomieszczeniach; 
8) poziom referencyjny — potencjał wykonawczy podmiotu leczniczego, uwzględniający w szczególności liczbę i kwalifikacje personelu medycznego, wyposażenie w sprzęt i aparaturę medyczną oraz możliwości diagnostyczno-terapeutyczne w określonej dziedzinie medycyny, zapewniające łącznie jakość i bezpieczeństwo udzielanych świadczeń zdrowotnych;

9) zakres kompetencji — rodzaj i minimalna liczba świadczeń zdrowotnych do wykonania przez podmiot medyczny o określonym poziomie referencyjnym $w$ danym okresie sprawozdawczym.

\section{Rozdział 2}

\section{Podmioty biorące udział w przeprowadzaniu audytów i nadawaniu poziomów referencyjności i zakresów kompetencji podmiotów leczniczych udzielających świadczeń zdrowotnych u chorych na nowotwory}

Art. 6. Tworzy się Krajową Radę ds. Onkologii i Hematologii, jako organ doradczy i opiniodawczy dla ministra właściwego do spraw zdrowia, zwaną dalej „Krajową Radą”.

Art. 7. Minister właściwy do spraw zdrowia powołuje i odwołuje członków Krajowej Rady spośród konsultantów krajowych, przedstawicieli towarzystw naukowych i świadczeniodawców z zakresu onkologii klinicznej, chirurgii onkologicznej, radioterapii onkologicznej, hematologii i dziedzin pokrewnych, w tym także wskazanych przez ministra zdrowia.

Art. 8. Przewodniczącego Krajowej Rady powołuje i odwołuje minister właściwy do spraw zdrowia.

Art. 9. Minister właściwy do spraw zdrowia nadaje Krajowej Radzie statut określający czas trwania kadencji, szczegółowy zakres, organizację i tryb działania oraz ustala zasady finansowania prac Krajowej Rady.

Art. 10. Do zadań Krajowej Rady należą w szczególności:

1) określanie potrzeb zdrowotnych w zakresie onkologii;

2) opiniowanie wytycznych diagnostyczno-leczniczych dla wszystkich nowotworów z uwzględnieniem typu i zaawansowania, jako obowiązujących we wszystkich podmiotach leczniczych realizujących świadczenia onkologiczne ze środków publicznych;

3) we współpracy z towarzystwami naukowymi i ośrodkiem akredytacji Centrum Monitorowania Jakości opracowanie i aktualizowanie parametrów poziomów referencyjności i zakresu kompetencji dla podmiotów leczniczych realizujących świadczenia onkologiczne ze środków publicznych;

4) we współpracy z ośrodkiem akredytacji Centrum Monitorowania Jakości przeprowadzanie audytów na wniosek podmiotów leczniczych realizujących świadczenia onkologiczne w celu uzyskania odpowiedniego poziomu referencyjności i zakresu kompetencji;

5) we współpracy z ośrodkiem akredytacji Centrum Monitorowania Jakości przeprowadzanie audytów następczych w podmiotach leczniczych realizujących świadczenia onkologiczne w celu utrzymania lub zmiany odpowiedniego poziomu referencyjności i/lub zakresu kompetencji;

6) zgłaszanie i opiniowanie inicjatyw w zakresie modyfikacji katalogu świadczeń gwarantowanych przez Narodowy Fundusz Zdrowia w zakresie profilaktyki i leczenia nowotworów;

7) zgłaszanie i opiniowanie programów szkoleń w zakresie kształcenia przeddyplomowego i specjalistycznego kształcenia podyplomowego w dziedzinie onkologii klinicznej, radioterapii onkologicznej i chirurgii onkologicznej;

8) zgłaszanie i opiniowanie projektów aktów prawnych w zakresie profilaktyki, diagnostyki i leczenia nowotworów;

9) prowadzenie krajowego rejestru referencyjnych podmiotów leczniczych wraz z wykazem posiadanych przez nie zakresów kompetencji;

10) opiniowanie raportów o częstości stosowania i skuteczności (przeżycia całkowite, wyleczenie, powikłania) oraz powikłań stosowanych metod diagnostyczno-terapeutycznych w ośrodkach realizujących świadczenia onkologiczne ze środków publicznych.

Art. 11. Narodowy Instytut Onkologii i Hematologii, zwany dalej „Instytutem”, jest instytutem badawczym o statusie Państwowego Instytutu Badawczego w rozumieniu ustawy z dnia 30 kwietnia 2010 r. o instytutach badawczych (DzU nr 96, poz. 618 oraz z 2011 r. nr 112, poz. 654 i nr 185, poz. 1092).

Art. 12. Instytut pełni rolę doradczą i opiniodawczą dla Krajowej Rady.

Art. 13. Do zadań Instytutu w zakresie współpracy z Krajową Radą należą:

1) monitorowanie potrzeb zdrowotnych wraz z oceną dostępności do świadczeń diagnostyczno-leczniczych w zakresie onkologii w poszczególnych regionach i województwach w kraju;

2) we współpracy z towarzystwami naukowymi opracowanie i aktualizowanie wytycznych diagnostyczno-leczniczych dla wszystkich nowotworów z uwzględnieniem typu i zaawansowania, jako obowiązujących we wszystkich jednostkach realizujących świadczenia onkologiczne ze środków publicznych;

3) we współpracy z Centrum Medycznym Kształcenia Podyplomowego opracowanie i aktualizowanie programów szkoleniowych w zakresie specjalistycznego kształcenia podyplomowego w onkologii klinicznej, radioterapii onkologicznej i chirurgii onkologicznej; 
4) zgłaszanie inicjatyw dotyczących modyfikacji katalogu świadczeń gwarantowanych przez Narodowy Fundusz Zdrowia, zwłaszcza w zakresie programów lekowych;

5) zgłaszanie projektów aktów prawnych w zakresie profilaktyki, diagnostyki i leczenia nowotworów;

6) opracowywanie raportów o częstości stosowania i skuteczności (przeżycia całkowite, wyleczenie, powikłania) oraz powikłań stosowanych metod diagnostyczno-terapeutycznych w ośrodkach realizujących świadczenia onkologiczne ze środków publicznych;

7) prowadzenie Krajowego Rejestru Zachorowań na Nowotwory.

\section{Rozdział 3}

\section{Poziomy referencyjności i zakresy kompetencji}

Art. 14. W oparciu o złożoność świadczeń onkologicznych do ich realizacji, kadrę specjalistów, ich doświadczenie i umiejętności, wymagane wyposażenie, strukturę organizacyjną i administracyjną, jakość i poziom kontaktów pacjent lekarz oraz specjalistycznej komunikacji poziomej i pionowej kadry ośrodka w zakresie wyboru optymalnej strategii diagnostyczno-leczniczej i jakości jej realizacji wyznacza się trzy poziomy referencyjności:

I. Podmioty realizujące świadczenia onkologiczne wyłącznie w ramach ambulatoryjnej opieki specjalistycznej;

II. Podmioty lecznicze niespełniające wymagań dla kryteriów poziomów I i III;

IIIA. Podmioty lecznicze wielospecjalistyczne realizujące wszystkie procedury diagnostyczne i lecznicze, w tym skojarzone, dla określonego typu nowotworu;

IIIB. Podmioty lecznicze wielospecjalistyczne realizujące wszystkie procedury diagnostyczne i lecznicze, w tym skojarzone, ale dla wybranych typów nowotworów;

IIIC. Podmioty lecznicze wielospecjalistyczne realizujące wszystkie procedury diagnostyczne i lecznicze, w tym skojarzone, dla wszystkich typów nowotworów i stopni ich zaawansowania.

Art. 15. Na podstawie parametrów zaproponowanych przez Krajową Radę, ośrodek akredytacji Centrum Monitorowania Jakości i inne podmioty Krajowa Rada opiniuje i rekomenduje ministrowi zdrowia zakres wymagań dla poziomów referencyjności wymienionych w art. 14, który określi je w drodze rozporządzenia.

Art. 16. Na podstawie rozporządzenia, o którym jest mowa w art. 15, Instytut we współpracy z ośrodkiem akredytacji Centrum Monitorowania Jakości opracowuje, a Krajowa Rada zatwierdza ankietę audytową — zwaną dalej ankietą — służącą parametrycznej ocenie poziomu referencyjności i zakresu kompetencji podmiotu leczniczego występującego o audyt.

Art. 17. Dane zawarte w ankiecie będą weryfikowane w trakcie przeprowadzania audytu przez zespół audytowy.

Art. 18. Poziom referencyjności i zakres kompetencji podmiotu leczniczego są przyznawane przez ministra zdrowia po spełnieniu wymagań ujętych w rozporządzeniu, o którym mowa w art. 15.

\section{Rozdział 4}

\section{Zasady przyznawania poziomów referencyjności i zakresów kompetencji}

Art. 19. Skład zespołu audytowego, o którym jest mowa w art. 17, wyznacza i zatwierdza minister zdrowia spośród członków wytypowanych przez Krajową Radę i Centrum Monitorowania Jakości.

Art. 20. Zespół audytowy składa się co najmniej z:

- dla chirurgii onkologicznej: lekarza z dodatkowym wykształceniem z zakresu zarządzania ochroną zdrowia lub/i uprawnieniami minimum audytora wewnętrznego, chirurga onkologa, anestezjologa, pielęgniarki instrumentariuszki;

- dla radioterapii onkologicznej: lekarza z dodatkowym wykształceniem z zakresu zarządzania ochroną zdrowia lub/i uprawnieniami minimum audytora wewnętrznego, radioterapeuty onkologicznego, fizyka medycznego, technika radioterapii;

- dla onkologii klinicznej: lekarza z dodatkowym wykształceniem z zakresu zarządzania ochroną zdrowia lub/i uprawnieniami minimum audytora wewnętrznego, onkologa klinicznego, hematologa, pielęgniarki onkologicznej, farmaceuty.

Art. 21. W skład zespołu nie mogą wchodzić pracownicy audytowanego podmiotu leczniczego i pracownicy innych podmiotów onkologicznych w województwie, w którym znajduje się audytowany podmiot.

Art. 22. Podmiot leczniczy występuje do ministra zdrowia z wnioskiem o audyt i wnosi ustaloną opłatę.

Art. 23. Przewodniczący zespołu audytowego z co najmniej jednomiesięcznym wyprzedzeniem wysyła do dyrektora/kierownika podmiotu leczniczego występującego o audyt ankietę audytową służącą parametrycznej ocenie poziomu referencyjności i zakresu kompetencji wraz z podaniem terminu audytu i składu zespołu przeprowadzającego audyt.

Art. 24. Treść raportu z przeprowadzonego audytu jest przedstawiana przez przewodniczącego zespołu audytowego dyrektorowi/kierownikowi podmiotu leczniczego, który ma możliwość wniesienia wyjaśnień, korekt, uzupełnień.

Art. 25. Ostateczna treść raportu z przeprowadzonego audytu, zaakceptowana przez przewodniczącego zespołu audytowego i dyrektora/kierownika podmiotu leczniczego, jest opiniowana pod względem formalno-prawnym przez ośrodek akredytacji Centrum 
Monitorowania Jakości, a pod względem merytorycznym przez Krajową Radę, która zwraca się z odpowiednim wnioskiem do ministra zdrowia o nadanie odpowiedniego poziomu referencyjności i zakresu kompetencji podmiotowi leczniczemu wnioskującemu o audyt.

Art. 26. Poziom referencyjności i zakres kompetencji są przyznawane podmiotowi leczniczemu na okres 3 lat.

Art. 27. Podmiot leczniczy jest zobowiązany do odbycia co najmniej jednego audytu następczego, nie rzadziej jednak niż raz na 3 lata.

Art. 28. Minister zdrowia uchyla nadany wcześniej poziom referencyjności i/lub zakres kompetencji, jeżeli podmiot leczniczy:

1) przestał spełniać warunki wymagane do uzyskania określonego poziomu referencyjności i/lub zakresu kompetencji;

2) nie poddał się audytowi lub uniemożliwia przeprowadzenie audytu następczego.

Art. 29. Minister zdrowia może przyznać warunkowo na określony czas określony poziom referencyjności i/lub zakres kompetencji w sytuacji, gdy ośrodek jest zobowiązany do uzupełnienia braków formalnych lub dokonania korekty nieprawidłowości niewpływających bezpośrednio na jakość i bezpieczeństwo udzielanych świadczeń zdrowotnych.

Art. 30. W przypadku odmowy nadania określonego poziomu referencyjności i/lub zakresu kompetencji podmiot leczniczy może przystąpić do ponownego audytu po usunięciu niezgodności będących podstawą odmownej decyzji i wniesieniu ustalonej opłaty.

Art. 31. Nadanie określonego poziomu referencyjności i zakresu kompetencji podmiotowi leczniczemu przez ministra zdrowia, w tym jego odmowa lub uchylenie wcześniejszej decyzji, następuje w drodze decyzji administracyjnej.

Art. 32. Krajowa Rada prowadzi rejestr referencyjnych podmiotów leczniczych wraz z wykazem posiadanych przez nie zakresów kompetencji.

Art. 33. Minister zdrowia określi, w drodze rozporządzenia, sposób prowadzenia Rejestru, o którym mowa w art. 32, uwzględniając dane objęte wpisem do rejestru oraz wzór księgi rejestrowej, a także sposób informowania podmiotu leczniczego o fakcie i przyczynie skreślenia z rejestru.

\section{Rozdział 5}

\section{Postanowienia końcowe}

Art. 34. W sprawach nieuregulowanych niniejszymi przepisami stosuje się przepisy kodeksu postępowania administracyjnego.

Art. 35. Rozporządzenie wchodzi w życie z dniem . 